\title{
ДИНАМІКА ЗАХВОРЮВАНОСТІ Й ПОШИРЕНОСТІ ПАТОЛОГІЇ ЩИТОПОДІБНОЇ ЗАЛОЗИ СЕРЕД ДОРОСЛОГО НАСЕЛЕННЯ УКРАЇНИ
}

\author{
ДВНЗ «Тернопільський державний медичний університет \\ імені І. Я. Горбачевського МОЗ України», м. Тернопіль, Україна
}

\begin{abstract}
Мета: оцінити стан захворюваності та динаміку поширеності захворювань щитоподібної залози серед дорослого населення України протягом 2013-2017 рр.

Матеріали і методи. Проведено порівняльний аналіз офріційних обліково-звітних статистичних даних МОз України та Інституту ендокринології та обміну речовин ім. В. П. Комісаренка АМН України «Основні показники діяльності ендокринологічної служби України».

Результати. В Україні зріс обсяг тиреоїдної патології і становить 46 \% від загальної ендокринологічної захворюваності. Найпоширенішою патологією є дифузний та вузловий зоб. їх рівень в західному регіоні вищий за середньодержавні показники та показники північно-східних областей. За 5 років зросла на 28,4 \% захворюваність на гіпотиреоз. Приріст тиреотоксикозу становив 8 \%, а поширеність тиреоїдитів зросла на $12,7 \%$.

Висока частота тиреоїдної патології залежить від недостатності йоду в харчуванні населення, незбалансованості мікроелементного і вітамінного складу в раціоні харчування на тлі погіршення екологічної ситуації та недостатньо ефективних профрілактичних заходів.

Висновки. Проведений аналіз свідчить про необхідність диференційованого підходу до проведення діагностики,
\end{abstract} лікування та профілактики хворих із різною патологією щитоподібної залози в окремих регіонах України.

КЛЮЧОВІ СЛОВА: захворюваність; поширеність; щитоподібна залоза.

Патологія ендокринної системи посідає провідне місце у структурі загальної захворюваності населення. За останні роки рівень ендокринологічних захворювань має тенденцію до зростання як у всьому світі, так і в нашій державі [3]. Відзначають зростання числа хворих на різні ендокринопатії, найбільш поширені серед них - захворювання щитоподібної залози (ЩЗ) та цукровий діабет (ЦД).

Підвищення інтересу до проблем тиреоїдної патології в Україні за останні роки спричинене її зростаючою поширеністю серед дорослого населення, високою частотою тимчасової та стійкої непрацездатності $[6,8]$. Провідними захворюваннями $€$ хвороби Щ3, абсолютна кількість випадків захворювань щЗ в Україні за останні 10 років збільшилася з 689 тис. до 1 млн 846 тис., за показниками поширеності, відповідно, 941,6 і 4210,4 випадку на 100 тис. населення. Патологія щ3 станом на 01.01.2018 р. становить $46 \%$ від загальної ендокринологічної захворюваності, враховуючи той фракт, що до захворювань щз належать зоб I-III ступенів (18,6\%), вузловий зоб (9,8\%), гіпотиреоз (6,4 \%), тиреоїдити (5,9\%), тиреотоксикоз (1,7 \%) та рак цієї залози (4,3 \%). Цукровий діабет займає загалом 39,9 \% структури ендокринологічних захворювань (рис. 1) [2].

Зростання захворюваності на щз потребує подальшого вивчення особливостей розвитку, клі-

(с) О. О. Чукур, 2018 нічного перебігу даних патологій, визначення схем лікування та профілактики залежно від регіональних особливостей [5].

Мета роботи: на основі комплексного вивчення стану здоров'я дорослого населення України оцінити стан та динаміку поширеності захворювань щ3.

Матеріали і методи. Проведено порівняльний аналіз офріційних обліково-звітних статистичних даних МО3 України та Інституту ендокринології та обміну речовин ім. В. П. Комісаренка АMH України «Основні показники діяльності ендокринологічної служби України» стосовно поширеності та захворюваності дорослого населення на патологію щ3 за останні 5 років - із 2013 до 2017 р. [4]. Статистичну обробку даних проводили з використанням кореляційно-регресійного аналізу поширеності захворювань щз за допомогою стандартного пакета статистичних розрахунків Microsoft Excel.

Результати дослідження та їх обговорення. У структурі захворювань щз, що входять до офіційної статистики, виділяють зоб, вузловий зоб, тиреотоксикоз, гіпотиреоз, тиреоїдити [9]. Оцінюючи поширеність патології щЗ в Україні в цілому, слід зазначити, що з 2013 до 2017 р. не тільки зріс обсяг тиреоїдної патології загалом, але й змінилася її структура [7].

Поширеність патології щ3 серед жителів різних регіонів України має певні відмінності. Так, 3 


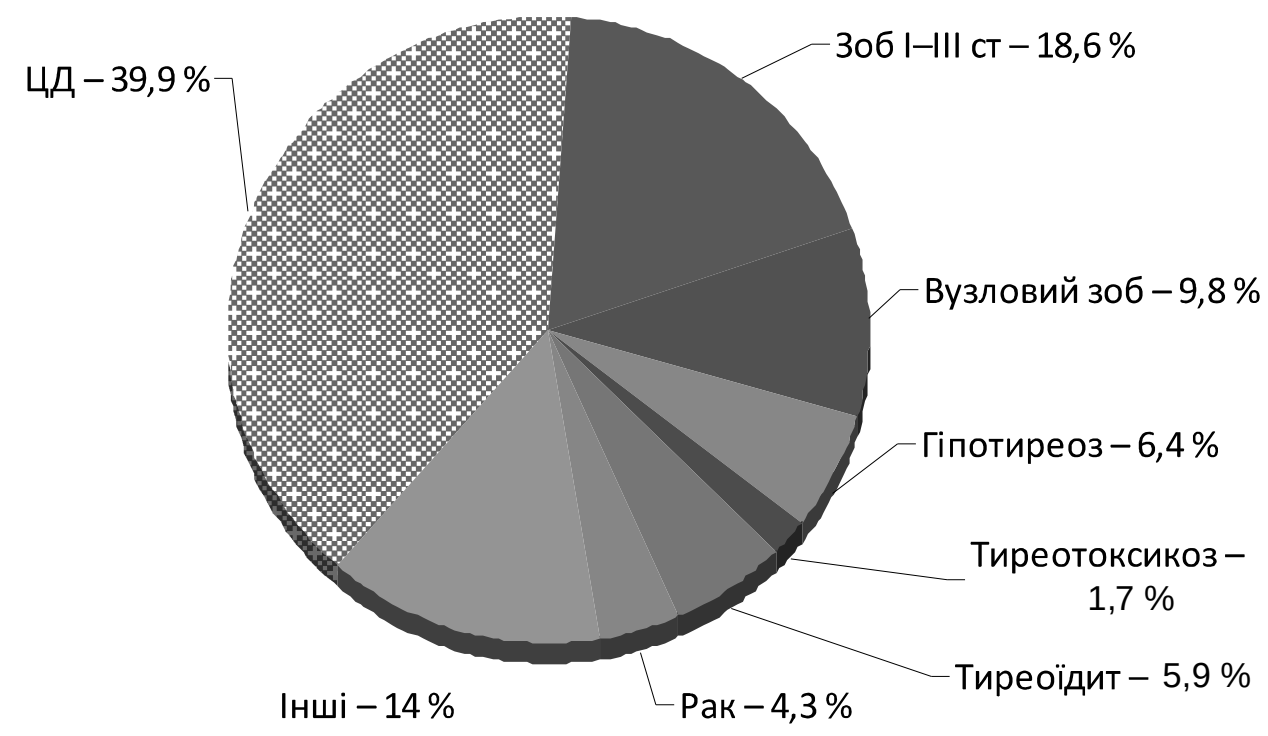

Рuc. 1. Структура хворих на ендокринопатії в Україні (станом на 01.01.2018р.).

2013 р. почали регулярно фріксувати зростання таких захворювань, як вузловий зоб, тиреоїдити, тиреотоксикоз, а частка гіпотиреозу зросла в 6,3 раза (табл. 1).

Найпоширенішою патологією ЩЗ на сьогодні залишається дифузний та вузловий зоб. Кількість зареєстрованих хворих на зоб в Україні вимірюється сотнями тисяч хворих. Основною причиною зоба $€$ недостатність йоду в харчуванні населення, безпосередній або опосередкований вплив різних негативних, у тому числі екологічних чинників [1]. Саме незбалансованість мікроелементного і вітамінного складу раціонів харчування на тлі погіршення екологічної ситуації та недостатньо ефективних профілактичних заходів на державному рівні зумовлює розвиток захворювань щз.

Таблиця 1. Поширеність захворювань щитоподібної залози серед дорослого населення у 2013 та 2017 рр. (на 100 тис. населення)

\begin{tabular}{|l|c|c|}
\hline \multicolumn{1}{|c|}{ Хвороби } & 2013 & 2017 \\
\hline Дифузний зоб І ступеня & 1287,8 & 1246,6 \\
\hline Дифузний зоб ІІ ступеня & 443,6 & 441,3 \\
\hline Вузловий зоб & 766,4 & 891,5 \\
\hline Гіпотиреоз & 251,6 & 302,8 \\
\hline Післяопераційний гіпотиреоз & 213,1 & 246,9 \\
\hline Тиреотоксикоз & 144,9 & 158,1 \\
\hline Тиреоїдит & 465,3 & 543,7 \\
\hline
\end{tabular}

Патологію щЗ спостерігають в різних регіонах України з частотою, що коливається іноді в десятки разів. Ілюстрацією цього $€$ показники поширеності дифузного зоба I i II-III ступенів та вузлового зоба в 2014 та 2017 рр. у різних регіонах України (за виключенням інформації з АР Крим та м. Севастополь, а також із регіонів зони АТО) (рис. 2).

Оцінюючи загальну кількість зареєстрованих хворих на зоб, спостерігають тенденцію до зниження показника поширеності зоба І ступеня. Число нових випадків у 2013 р. становило 48 649, а в 2017 р. - 34861 . Протягом останніх 5 років зоб II-III ступенів теж мав тенденцію до незначного зниження, так у 2013 р. поширеність становила 156613 випадків, а в 2017 р. - 153556 випадків, що в перерахунку на 100 тис. населення становить 31,5 та 28,6 нових випадків. Ці дані реально відтворюють позитивну динаміку профрілактичної роботи та освітньо-інформаційної обізнаності населення в Україні щодо зниження захворювань щЗ. Варто відзначити, що їх рівень у більшості областей західного регіону вищий за середньодержавні показники та показники північно-східних областей. Це пов'язано зі значно більшою захворюваністю населення західних областей на тиреопатологію і як наслідок ендемічності цих регіонів з йододесріциту.

Аналізуючи поширеність вузлового зоба серед дорослого населення України, відзначають зростання цієї патології з кожним роком. Офріційні дані щодо кількості хворих подано на рисунку 3. Кількість хворих на цю патологію збільшувалася 


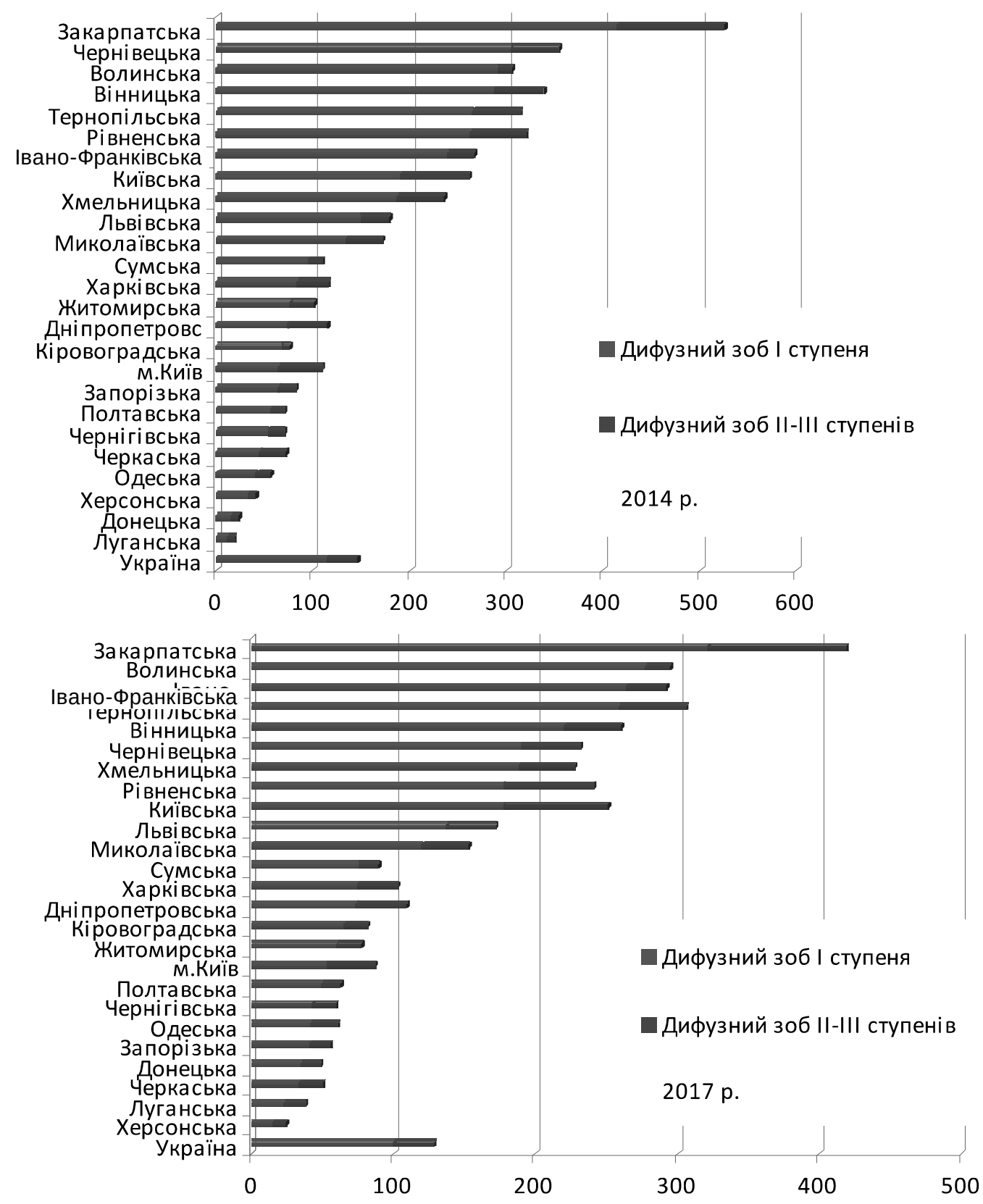

Puc. 2. Поширеність дифузного зоба I та II-III ступенів у різних регіонах України станом на 2014 та 2017 рр. (на 100 тис. населення).

щорічно майже на 10 \%. Причиною такого зростання частоти випадків вузлового зоба в Україні $€$ наслідки аварії на ЧАЕС, а також негативний стан довкілля в зв'язку з природним дефіцитом йоду, селену та інших мікроелементів. Наявні високі показники захворюваності на доброякісні новоутворення Щ3 в Україні, у 2014 р. було вперше виявлено 28850 хворих на вузловий зоб (показник захворюваності становив 81,7 на 100 тис. населення), у 2015 р. - 29982 хворих (83,6 на 100 тис. населення), в 2016 р. - 30012 хворих (87,5 на 100 тис. населення), за 2017 р. - 33721 хворих (90,2 на 100 тис. населення). Діагностика вузлового зоба суттєво покращилась за останні роки за рахунок сучасних ультразвукових досліджень, що і вказує на загальне зростання захворювання.
Порівняно $з$ іншою патологією тиреотоксикоз спостерігають значно рідше, але кількість випадків також вимірюють десятками тисяч хворих. Поширеність тиреотоксикозу в Україні за 2013 р. становила 155,2 на 100 тис. населення, а захворюваність становила 13,8 випадку на 100 тис. населення. У 2017 р. поширеність становила 168,1 на 100 тис. населення, а захворюваність діагностували в 16,4 випадку на 100 тис. населення. За 5 років приріст захворювання становив близько 8 \%. Захворюваність на цю нозологію також поступово зростає, число нових випадків тиреотоксикозу в 2013 р. становило 4 999, а в 2017 р. 6027 на 100 тис. населення.

За останні роки стрімко зростає поширеність тиреоїдитів на території України. Під цим 


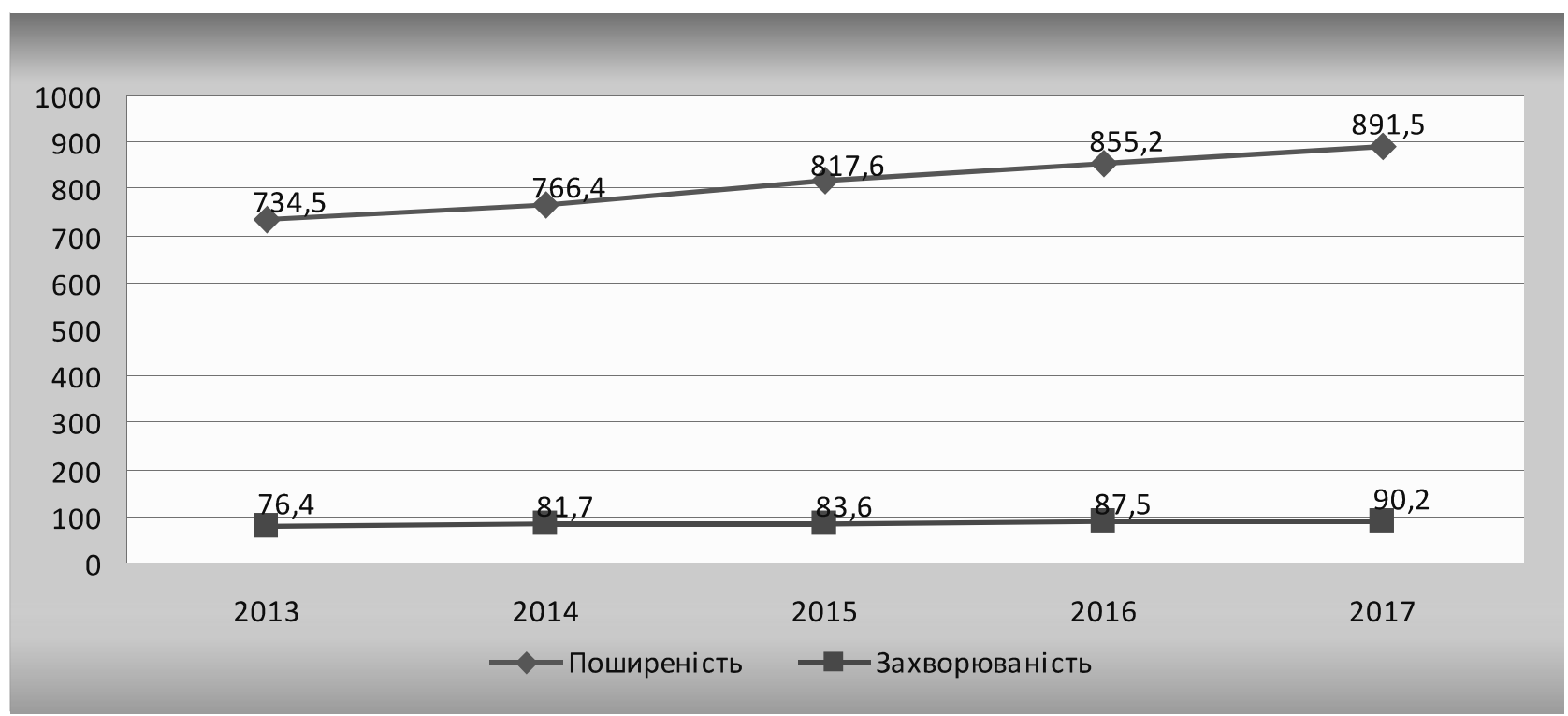

PUс. 3. Поширеність та захворюваність на вузловий зоб серед дорослого населення у 2013-2017 pp.

діагнозом об'єднано гострі, підгострі, хронічні тиреоїдити та автоімунні тиреоїдити. Поширеність тиреоїдиту в Україні за останні 5 років зросла на 12,7 \%, а в перерахунку на 100 тис. населення на 38 \%. Зазначимо, що в 2013 р. поширеність становила 16330 випадків тиреоїдиту, а в 2017 р. 18403 випадків, що в перерахунку на 100 тис. населення становить 37,0 та 49,2 нових випадків (рис. 4).

Гіпотиреоз - одна 3 найчастіших патологій ендокринної системи, що викликана десріцитом тиреоїдних гормонів або зниженням їх біологічного ефректу на тканинному рівні. Станом на 01.01.2018 р. в Україні зареєстровано понад 105 тис. хворих на гіпотиреоз. Поширеність цього захворювання серед населення постійно збільшується і спостерігається поступове зростання кількості випадків розвитку патології. За 5 років кількість випадків гіпотиреозу зросла на 28,4 \%, а в розрахунку на 100 тис. населення - майже на 30 випадків на 100 тис. (рис. 5).

Характеризуючи гіпотиреоз як результат розвитку інших захворювань, необхідно пам'ятати, що значну роль у зростанні кількості випадків цієї патології відіграють оперативні втручання на Щ3. Основною причиною для таких операцій є рак Щ3, вузловий зоб, тиреотоксикоз [10]. Усього внаслідок оперативних втручань протягом 2017 р. зареєстровано 85915 випадків гіпотиреозу ( рис. 6).

У цілому зростання захворюваності та поширеності захворювань щз завдають великої соціально-економічної шкоди, що визначаються витратами на медичне обслуговування та соціальне

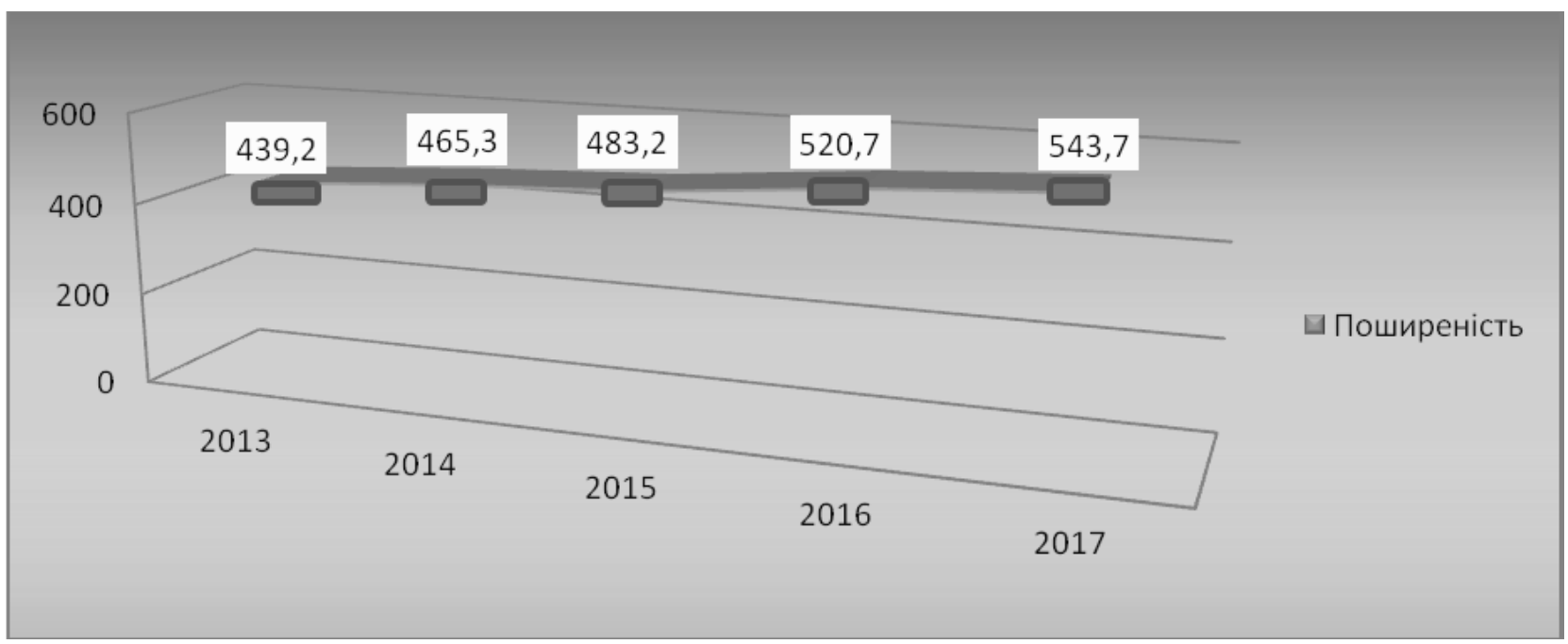

Puc. 4. Поширеність та захворюваність на тиреоїдити в Україні станом на 2013-2017 рр. (на 100 тис. населення). 


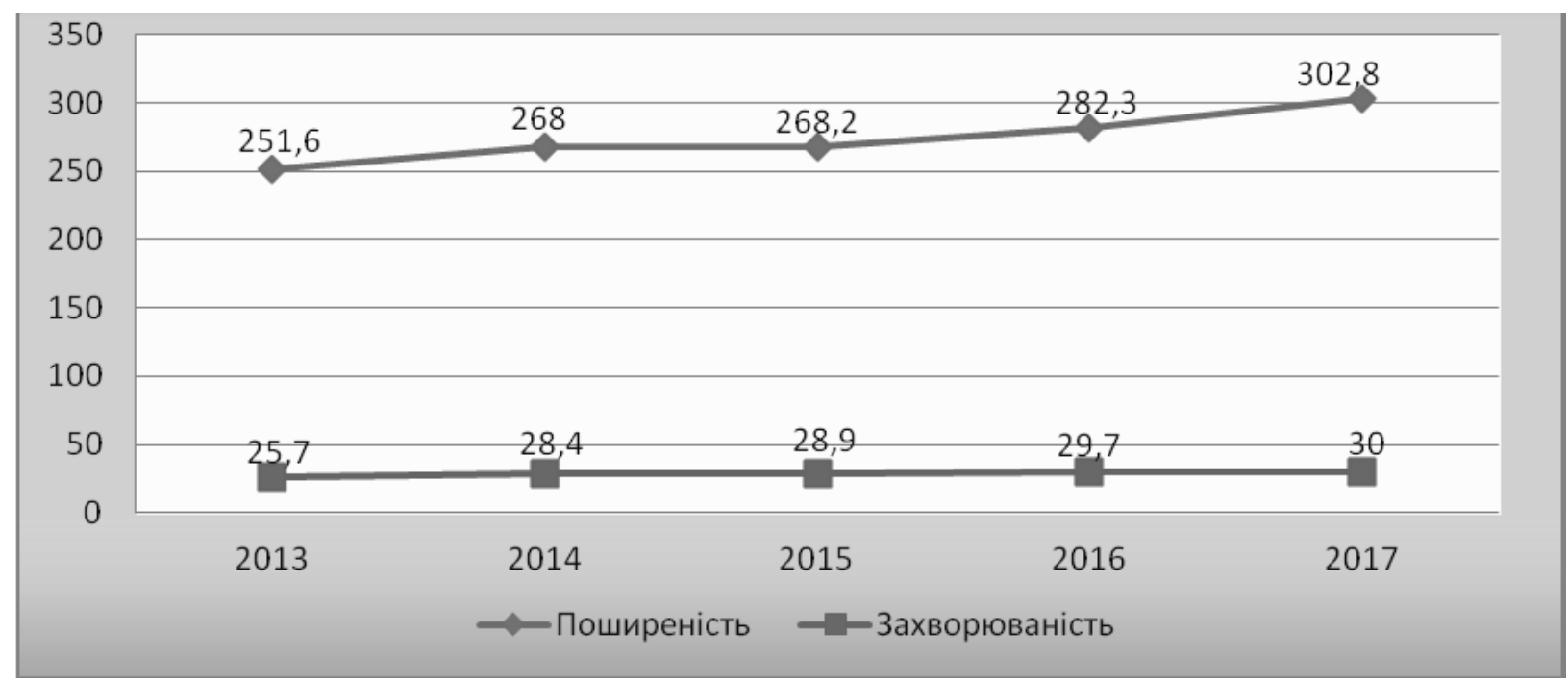

Puc. 5. Поширеність та захворюваність на набутий гіпотиреоз в Україні станом на 2013-2017 рр.

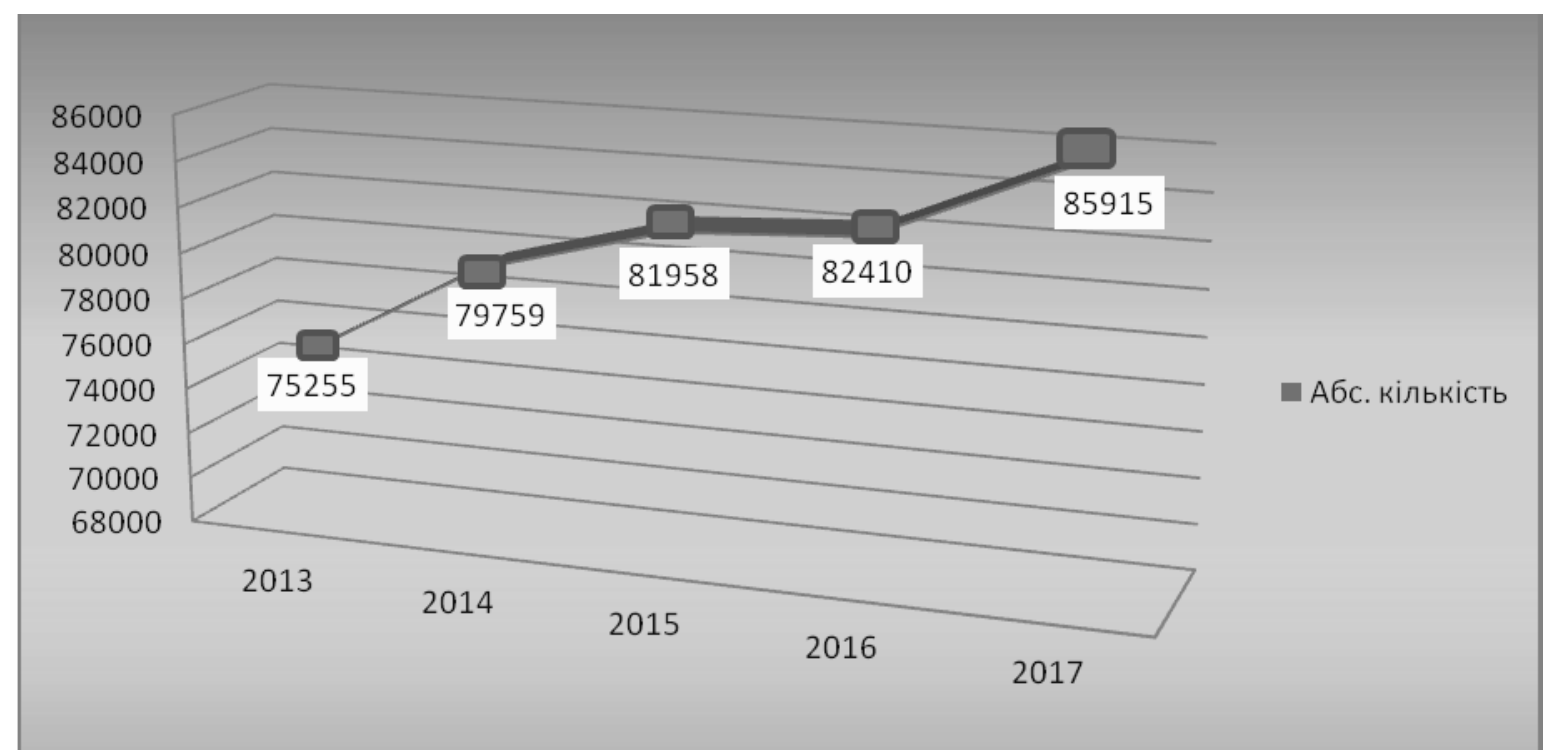

Puc. 6. Кількість випадків післяопераційного гіпотиреозу серед дорослого населення в Україні у 2013-2017 рр. (абс. кількість).

забезпечення (у зв'язку із втратою працездатності, інвалідністю, передчасною смертю хворих).

\section{Висновки}

Проведений порівняльний аналіз захворюваності та поширеності захворювань щз серед дорослого населення України (на 100 тис. населення) протягом 2013-2017 рр. свідчить про суттєве зростання загальної кількості тиреоїдної патології в цілому. Зріс не тільки обсяг, але змінилася і її структура (велику роль відіграє покращення якості діагностики цих патологій).

Відзначають різну динаміку поширеності захворювань щЗ в окремих регіонах України, що зумовлено різними географічними умовами та зменшенням кількості населення в Україні за останні роки за рахунок анексованого Криму та регіонів зони АТО. Суттєво зменшилася захворюваність на зоб І ступеня та відзначається незначна тенденція до зниження захворюваності на зоб II-III ступенів в Україні загалом, однак кількість вперше виявлених випадків у більшості областей західного регіону вища за середньодержавні показники. Наявні високі показники захворюваності на доброякісні новоутворення щЗ в Україні, збільшилася поширеність та захворюваність населення на вузловий зоб у центральних та західних областях. Значно зросла захворюваність на гіпотиреоз, особливо за рахунок збільшення кількості хворих із післяопераційним гіпотиреозом у всіх регіонах України. Практично не змінилася ситуація на тиреотоксикоз, спостерігають поступове зростання захворюваності на цю нозологію. 
За останні роки зростає поширеність тиреоїдитів по всій території України.

Проведений аналіз свідчить про необхідність диференційованого підходу до проведення діагностики, лікування та профрілактики хворих із різною патологією щЗ в окремих регіонах України.
Перспективи подальших досліджень полягають у вивченні взаємозв'язків поширеності захворювань щ3 із йодним дефріцитом та дефіцитом вітаміну D у Тернопільському регіоні.

\section{Список літератури}

1. Аналіз поширеності тиреоїдної патології та захворюваності на неї серед населення Київської області та України за 2007-2017рр. / В. І. Ткаченко, Я. А. Максимець, Н. В. Видиборець, О. Ф. Коваленко // Міжнародний ендокринологічний журнал. - 2018. - № 3 (14). - С. 272-277.

2. Зелінська Н. Б. Патологія щитоподібної залози у дитячого населення України / Н. Б. Зелінська, О. С. Ларін // Клінічна ендокринологія та ендокринна хірургія. - 2016. - № 3 (55). - С. 76-81.

3. Кравченко В. І. Динаміка захворюваності на патологію щитоподібної залози в Україні / В. І. Кравченко, С. В. Постол // Міжнародний ендокринологічний журнал. - 2011. - № 3 (35). - С. 10-14.

4. Основні показники діяльності ендокринологічної служби України за 2017 рік. АМН та МОЗ України, ДУ «Інститут ендокринології та обміну речовин ім. В. П. Комісаренка НАМН України», 2013-2017 рр.

5. Паньків В. І. Практична тиреоїдологія / В. І. Паньків. - Донецьк : Видавець Заславський О. Ю., 2011. - 224 с.

6. Скрипник Н. В. Динаміка захворюваності й поширеності вузлових утворень щитоподібної в Україні та на Прикарпатті / Н. В.Скрипник, О. В. Марусин // Практикуючий лікар. - 2017. - № 2 (6). - С. 26-29.

7. Стандарти надання медичної допомоги хворим з патологічними станами щитоподібної залози в умовах дії негативних чинників довкілля / за ред. д. мед. н. О. В. Камінського. - 2-ге вид. - К. : Старт-98, 2015. - 224 с.

8. Global epidemiology of hyperthyroidism and hypothyroidism / P. N Taylor, D. Albrecht, A. Scholz [et al.] // Nat Rev. Endocrinol. - 2018. - No. 14(5). - P. 301-316.

9. Thyroid examination in highly radiationexposed workers after the Chernobyl accident / B. O. Boehm, M. Steinert, J. W. Dietrich [et al.] // Eur. J. Endocrinol. - 2009. - No. 4. - P. 625-630.

10. Thyroid neoplasia risk is increased nearly 30 years after the Chernobyl accident / M. D. Tronko, A. V. Brenner, T. Bogdanova [et al.] // Int. J. Cancer. - 2017. doi: 10.1002/ijc.30857.

\section{References}

1. Tkachenko, V.I., Maksimets, Ya.A., Vydyborets, N.V., \& Kovalenko, O.F. (2018). Analiz poshyrenosti tyreoidnoi patolohii ta zakhvoriuvanosti na nei sered naselennia Kyivskoi oblasti ta Ukrainy za 2007-2017 rr. [Analysis of the prevalence of thyroid pathology and its incidence among the population of Kyiv oblast and Ukraine for 2007-2017]. Mizhnarodnyi endokrynolohichnyi zhurnal - International Endocrinology Journal, 3 (14), 272-277 [in Ukrainian].

2. Zelinska, N.B., \& Larin, O.S. (2016). Patolohiia shchytopodibnoi zalozy u dytiachoho naselennia Ukrainy [Pathology of the thyroid gland in the children's population of Ukraine]. Klinichna endokrynolohiia ta endokrynna khirurhiia - Clinical Endocrinology and Endocrine Surgery, 3 (55), 76-81 [in Ukrainian].

3. Kravchenko, V.I., \& Postol, S.V. (2011). Dynamika zakhvoriuvanosti na patolohiiu shchytopodibnoi zalozy v Ukraini [Dynamics of pathology of the thyroid gland in Ukraine]. Mizhnarodnyi endokrynolohichnyi zhurnal - International Endocrinology Journal, 3 (35), 10-14 [in Ukrainian].

4. Osnovni pokaznyky diialnosti endokrynolohichnoi sluzhby Ukrainy za 2017 rik [Main indicators of the activity of the endocrinology service of Ukraine for 2017]. AMN ta MOZ Ukrainy, DU "Instytut endokrynolohii ta obminu rechovyn im. V.P. Komisarenka NAMN Ukrainy", 2013-2017 rr. - Academy of Medical Sciences of Ukraine and Ministry of Health of Ukraine, Institute of Endocrinology and Metabolism by V.P. Komisarenko of NAMS of Ukraine", 2013-2017 [in Ukrainian]. 5. Pankov, V.I. (2011). Praktychna tyreoidolohiia [Practical thyroidology]. Donetsk: Publisher Zaslavskyi O.Yu [in Ukrainian]. 6. Skrypnyk, N.V., \& Marusin, O.V. (2017). Dynamika zakhvoriuvanosti i poshyrenosti vuzlovykh utvoren shchytopodibnoi v Ukraini ta na Prykarpatti [Dynamics of morbidity and prevalence of nodal formations of the thyroid in Ukraine and in the Carpathians]. Praktykuiuchyi likar - Practicing Physician, 2 (6), 26-29 [in Ukrainian].

7. Kaminskyi, O.V. (Ed.). (2015). Standarty nadannia medychnoi dopomohy khvorym z patolohichnymy stanamy shchytopodibnoi zalozy $v$ umovakh dii nehatyvnykh chynnykiv dovkillia (2-e vyd.) [Standards for the provision of medical care to patients with pathological conditions of the thyroid gland under conditions of negative environmental factors (2nd ed.)]. Kyiv: Start 98 [in Ukrainian].

8. Taylor, P.N., Albrecht, D., \& Scholz, A. (2018). Global epidemiology of hyperthyroidism and hypothyroidism. Nat. Rev. Endocrinol., 14 (5), 301-316.

9. Boehm, B.O., Steinert, M., \& Dietrich, J.W. (2009). Thyroid examination in highly radiationexposed workers after the Chernobyl accident. Eur. J. Endocrinol., 4, 625-630.

10. Tronko, M.D., Brenner, A.V., \& Bogdanova, T. (2017). Thyroid neoplasia risk is increased nearly 30 years after the Chernobyl accident. Int. J. Cancer. 


\section{ДИНАМИКА ЗАБОЛЕВАЕМОСТИ И РАСПРОСТРАНЕННОСТИ ПАТОЛОГИИ ЩИТОВИДНОЙ} ЖЕЛЕЗЫ СРЕДИ ВЗРОСЛОГО НАСЕЛЕНИЯ УКРАИНЫ

О. А. Чукур

ГВУЗ «Тернопольский государственный медицинский университет имени И. Я. Горбачевского МЗ Украины»,

г. Тернополь, Украина

Цель: оценить состояние заболеваемости и динамику распространенности заболеваний щитовидной железы среди взрослого населения Украины в течение 2013-2017 гг.

Материалы и методы. Проведен сравнительный анализ официальных учетно-отчетных статистических данных МЗ Украины и Института эндокринологии и обмена веществ им. В. П. Комиссаренко АМН Украины «Основные показатели деятельности эндокринологической службы Украины».

Результаты. По Украине вырос объем тиреоидной патологии и составляет $46 \%$ от общей эндокринологической заболеваемости. Самой распространенной патологией является дисфузный и узловой зоб. Их уровень в западном регионе выше среднегосударственных показателей и показателей северо-восточных областей. За 5 лет выросла на 28,4 \% заболеваемость гипотиреозом. Прирост тиреотоксикоза составил 8 \%, а распространенность тиреоидитов выросла на 12,7 \%.

Высокая частота тиреоидной патологии зависит от недостаточности йода в питании населения, несбалансированности микроэлементного и витаминного состава в рационе питания на фоне ухудшения экологической ситуации и недостаточно эфффективных профилактических мероприятий.

Выводы. Проведенный анализ свидетельствует о необходимости дифференцированного подхода к проведению диагностики, лечения и профилактики больных с различной патологией щитовидной железы в отдельных регионах Украины.

КЛЮЧЕВЫЕ СЛОВА: заболеваемость; распространенность; щитовидная железа.

\section{DYNAMICS OF MORBIDITY AND EXPANSION OF PATHOLOGY OF THE THYROID GLAND AMONG ADULT POPULATION OF UKRAINE \\ O. O. Chukur \\ I. Horbachevsky Ternopil State Medical University}

Purpose: to assess the state of morbidity and the dynamics of the prevalence of thyroid disease among the adult population of Ukraine during 2013-2017.

Materials and Methods. A comparative analysis of official accounting and reporting statistics of the Ministry of Health of Ukraine and the Institute of Endocrinology and Metabolism named after V.P. Komissarenko of the Academy of Medical Sciences of Ukraine "The main indicators of the activity of the endocrinological service of Ukraine" was conducted.

Results. In Ukraine, the volume of thyroid pathology increased and is $46 \%$ of the total endocrinological morbidity. The most common pathology is diffuse and nodular goiter. Their level in the western region is higher than the national average and indicators of the north-eastern regions. Incidence of hypothyroidism increased by $28.4 \%$ for 5 years. The increase in thyrotoxicosis was $8 \%$, and the prevalence of thyroiditis increased by $12.7 \%$.

The high frequency of thyroid pathology depends on the lack of iodine in the diet of the population, the imbalance of the trace element and vitamin content in the diet due to the deterioration of the environmental situation and inadequate preventive measures.

Conclusions. The analysis is carried out the need for a differentiated approach to the diagnosis, treatment and prophylaxis of patients with different pathology of the thyroid gland in some regions of Ukraine.

KEY WORDS: morbidity; prevalence;thyroid gland.

Рукопис надійшов до редакції 20.11.2018 p.

\section{Відомості про автора:}

Чукур Оксана Олександрівна - аспірант кафедри внутрішньої медицини № 1 дВНЗ «Тернопільський державний медичний університет імені І. Я. Горбачевського МОЗ України»; тел.: +38(097) 821-88-09. 